\title{
Mahogany fruit material exploration for an essential oil nebulizer in the new normal adaptation
}

\author{
H. Azhar, A.S.M. Atamtajani \& Andrianto \\ Telkom University, Bandung, Indonesia
}

\begin{abstract}
The material investigation strategy in product design advancement may be a typical methodology that results in numerous unusual chances. Our examination centers around the investigation of material use from Swietenia macrophylla, usually known as mahogany, a local South American plant that is commonly naturalized in south-east Asian nations. This plant is regularly developed in estates since it yields veritable mahogany lumber which is very popular for making furniture. The plant delivers a gigantic measure of side natural product, its fruit, that tragically can't be improved upon at this point in society. In light of the perception and test result, its fruit can be utilized as elective specialty materials that advance the item's esteem with the aesthetical eco-plan approach. A viable cycle must be applied to treat the natural product fittingly with an appropriate pressed wood blend. This test method is applied to the essential oil nebulizer, one of the most popular items in this area of new normal. The correct treatment of this mahogany organic product is expected to be a future elective material for wood mix in making a wide scope of specialty products.
\end{abstract}

Keywords: Kata Kunci: material, exploration, mahogany, nebulizer, new normal

\section{INTRODUCTION}

The issue of national wood deficit demand drove the researcher to find wood-alternative materials for crafts and furniture manufacturing. According to Pengkajian and Perdagangan (2017) Badan Pengkajian dan Pengembangan Perdagangan (2017), the national wood demand has reached $57-58$ million $\mathrm{m}^{3} /$ year while the production capacity of natural forests and plantations is around 45.8 million $\mathrm{m}^{3} /$ year. This means Indonesia still has a wood deficit of around 11 million $\mathrm{m}^{3} /$ year.

The Forest Management Center (2017) reported that mahogany (Swietenia macrophylla) is one of the easiest solid woods to cultivate with the plantation reaching 54,000 ha in Indonesia. However, the mahogany plantation has a plentifully discarded side product, its fruit. The abundant mahogany fruit reaches 216 tons/year and is still not used properly.

This fact inspires the author to explore the mahogany fruit material for wood combination in developing a new product. The main purpose of utilizing the mahogany fruit material is to create an aesthetical wood combination alternative material for making crafts and furniture. The research focuses on the utilization of mahogany fruit for creating an essential oil nebulizer design, a relaxing product for helping people in the new normal adaptation. An essential oil nebulizer was chosen to be developed with this wood combination material to develop one of the most wanted products during the pandemic into a brand new product with an eco-design approach.

\section{RESEARCH METHOD}

\subsection{Research approach}

The research method for this material exploration and design process was a qualitative approach. This qualitative method uses visual strategies as study material to process the research object. The study can be categorized as an entrenched case study (Flick, 2014). 


\subsection{Data collection techniques}

The empirical data collection was gathered from archival information and semi-structured interviews from the wood crafters in Banyuwangi, East Java, Indonesia. Furthermore, the author also conducted field observations about the utilization of mahogany fruit in the plantation area.

\subsection{Design method}

The design method for this research focuses on the interchangeable method by making an adjustment or removing the visual element parts of the essential oil nebulizer. Hence, the author focuses on the remaking process of the visual appearance from the existing product, an essential oil nebulizer. According to Masry (2010), the visual strategy can be an added value for an object's visual quality based on the impact of the visual elements on human perception.

\section{DISCUSSION AND RESULT}

\subsection{Mahogany fruit utilization}

Forest Management (2017) reported that mahogany fruit production has reached 216 tons/year and has not been utilized yet for craft or mass furniture production. However, some studies revealed that mahogany fruit has many uses for antiseptics and plantation. Gultom et al. (2014) discovered that the mahogany fruit, actually its seeds, are useful as an insecticide to control soybean plant pests. Another study by Koneri (2016) proved that the mahogany fruit can be applied for Aedes aegypti larvae insecticide, as well as various traditional medicinal herbs. To optimize the abundant mahogany fruit that is treated like trash, the author focuses on research to make a combination of material products from the fruit.

\subsection{Essential oil nebulizer and new normal adaptation}

The World Health Organization (WHO) declared a pandemic caused by the SARS-CoV-2 on March 11,2020 . Since then, the virus that was first seen in Wuhan, China, has subsequently appeared in many countries around the world. Regarding this pandemic, the world is now facing a new normal adaptation such as physical distancing, masking for all, and the way people work and learn. Working from home is a new culture and there is no longer a need for frequent face-to-face meetings. The author focuses on assisting productive ambient working from home.

According to Lehrner et al. (2005) and Goes et al. (2012), the study determined that particular ambient odors can reduce anxiety and improve a worker's mood in the office. The evidence clearly proves that it is effective to manage symptoms like stress, anxiety, and insomnia. It makes the demand for essential oil diffusers and nebulizers raise significantly in the global market during a pandemic.

Essential oils considered to be "antiviral" are not universal virus killers. One virus that can be tackled by essential oil is influenza (Wu et al., 2012). However, there is no research on essential oil and SARS-CoV-2 at present that acclaimed any essential oils as antiviral for people with COVID-19. Therefore, the use of aromatherapy focuses on reducing anxiety and improving mood.

\subsection{Material exploration}

Mahogany plants only bloom after the age of 7 years. When the fruit is still young, it is green and becomes brown after it is ripe. There are flat-shaped seeds with a rather thick tip and blackish-brown winged colors inside the fruit. This material experiment uses the half-ripe mahogany fruit, so its fruit and seeds were still strongly fused. It will be dried in the sun to brown. 


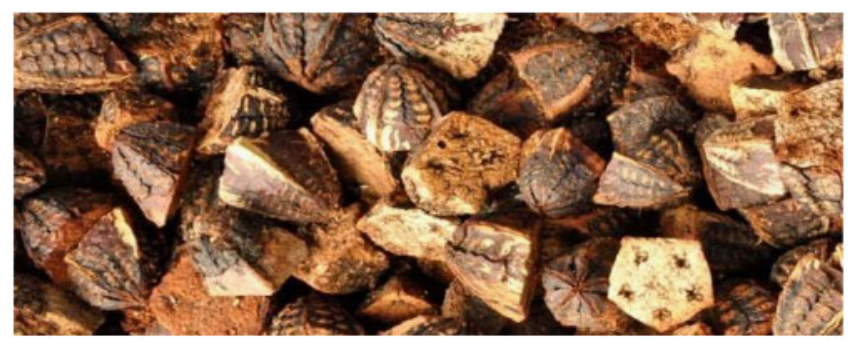

Figure 1. The dried mahogany fruit. (Source: personal documentation, 2020)

After the mahogany fruit is dried, it is cut flat with the same thickness. The pieces will be shaped like a pentagon following the natural shape of mahogany.

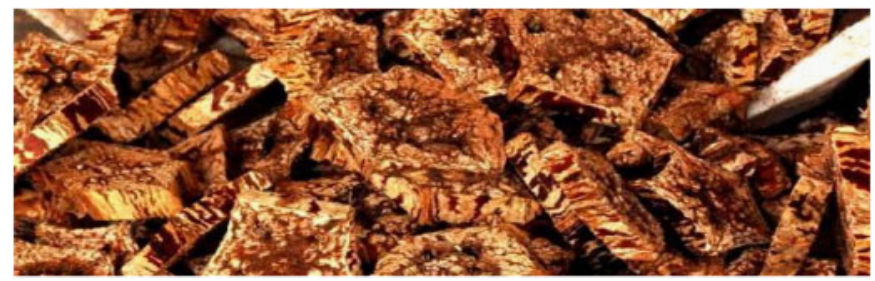

Figure 2. The cut-flat mahogany fruit.(Source: personal documentation, 2020)

The mahogany fruit that has been cut flat will be manually trimmed to be the same size. This measure aims to make mahogany fruit easily combined with the other material, plywood.

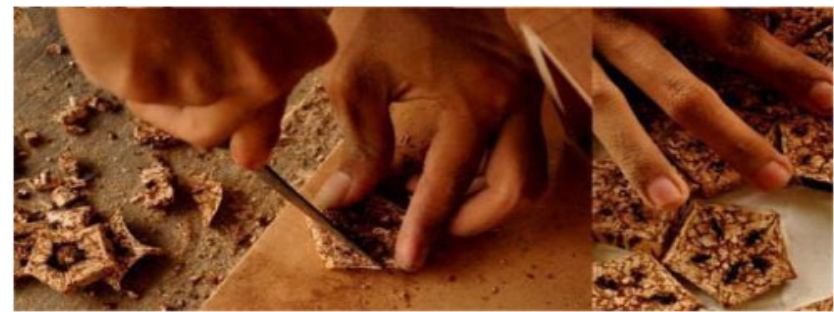

Figure 3. The size standardization process.(Source: personal documentation, 2020)

The sorted size of mahogany fruits will be arranged in an aesthetic order with plywood as its material combination. Pieces of mahogany fruit are neatly arranged and glued together with plywood. After it sticks to plywood tightly, wait for it until dry and then tidy up with electric sandpaper.

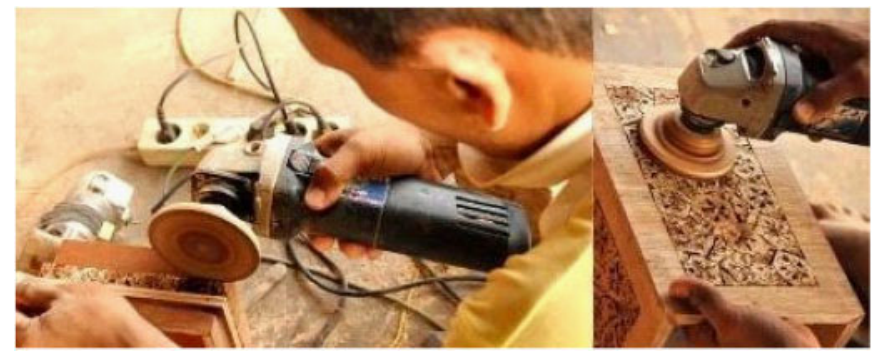

Figure 4. The sanding fragment activity. (Source: personal documentation, 2020) 
The results of sanding material combination between mahogany fruit and plywood can be used as an alternative material combination with added aesthetic value. This result can be used to create any kind of craft and wood furniture.

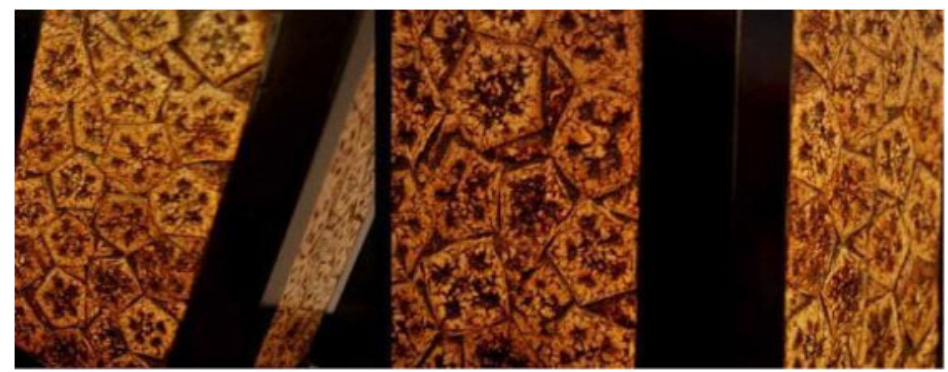

Figure 5. The completed combination material of mahogany fruit. (Source: personal documentation, 2020)

\subsection{Term of references}

Term of reference serves as design limitation so the author can create the expected design:

1. Product Considerations. The product has a simple form and focuses on its function with an aesthetic combination material of mahogany fruit and plywood.

2. Product Limitation. The product uses the existing applied technology of an essential oil nebulizer on the market. So, the design will be adjusted to the nebulizer that already exists. Besides, this product can spread the aromatherapy odor only in one room.

3. Product Description. The target users are people who hardly manage symptoms like stress, anxiety, and insomnia. During the so-called new normal adaptation in the COVID-19 pandemic, people are forced to stay at home. Some people are struggling with the pandemic situation and cannot go outside for months. The essential oil nebulizer will help people reduce anxiety and improve their mood while working from home.

\subsection{Final design}

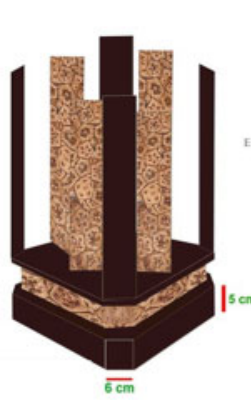

3 D VIE W
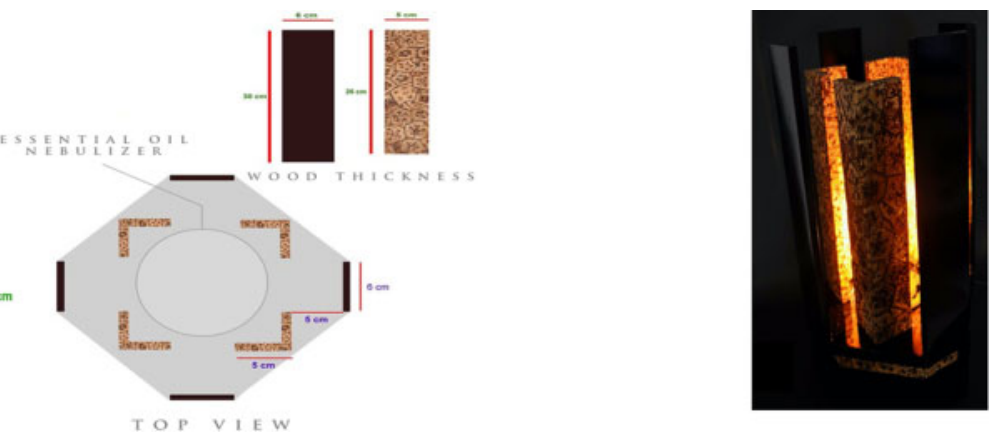

Figure 6. The final design. (Source: personal documentation, 2020) 


\section{CONCLUSION}

The national issue of a wood deficit has driven researchers to explore alternative materials for crafting and furniture products. The material exploration research of mahogany fruit revealed that the fruit which is treated like trash actually can be used as an alternative combination material to craft diverse creations. With the mahogany fruit combination, an applied product, such as an essential oil nebulizer in this research, becomes more attractive with a natural classic appearance. To create this combination of alternative material, the author must apply the proper treatment for the fruit. This research result can be used to develop other products from a combination of material exploration.

\section{REFERENCES}

Balai Pengelola Hutan Lebak. 2017. Budidaya Mahoni (Swietenia Macrophylla King).

Flick, U. 2014. Introducing Research Methods. Sage, London.

Goes, T., Antunes, F., Alves, P., and Teixeira-Silva, F. 2012. Effect of sweet orange aroma on experimental anxiety in humans. Journal of alternative and complementary medicine. 18(8):798-804.

Gultom, R.M., Pangestiningsih, Y., and Lubis, L. 2014. Pengaruh Beberapa Insektisida Terhadap Hama Lamprosema Indicata F. dan Spodoptera Litura F. Pada Tanaman Kedelai. Jurnal Online Agroekoteknologi 2(3):1159-1164

Koneri, R. 2016. Uji Ekstrak Biji Mahoni (Swietenia Macrophylla) terhadap Larva Aedes Aegypti. JURNAL MKMI 12(4):2016-223

Krisnawati, H., Kallio, M., and Kanninen, M. 2011. Swietenia macrophylla King. Ecology, Silviculture and Productivity. CIFOR, Bogor.

Lehrner, J., Marwinski, G., Lehr, S., Johren, P., and Deecke, L. 2005. Ambient odors of orange and lavender reduce anxiety and improve mood in a dental office. Physiology \& Behavior 86.

Masri, A. 2010. Strategi Visual, Formalistik dan Semiotik. Bantul: Jalasutra

Pengkajian, B. and Perdagangan, P. 2017. Info Komoditi Furnitur. Kementerian Perdagangan Republik Indonesia.

Wu, Q., Wang, W., Dai, X., Wang, Z., Shen, Z., Ying, H., and Yu, C. 2012. Chemical compositions and anti-influenza activities of essential oils from Mosla dianthera. Journal of Ethnopharmacology 139(2): 668-671. 